\title{
Perioperative platelet transfusion: recommenda- tions of the Agence française de sécurité sanitaire des produits de santé (AFSSaPS) 2003
}

\author{
[Transfusion périopératoire de plaquettes : recommandations de l'Agence
}

française de sécurité sanitaire des produits de santé (AFSSaPS) 2003]

Charles Marc Samama MD PhD, ${ }^{*}$ Rachid Djoudi MD $\nmid \dagger$ Thomas Lecompte MD PhD, $\ddagger$

Nathalie Nathan-Denizot MD PhD, $\mathbb{S}$ Jean-François Schved MD PhD, II and the AFSSAPS Expert Group

Purpose: To present the recommendations of the Agence Française de Sécurité Sanitaire des Produits de Santé (AFSSaPS; French Safety Agency for Health Products).

Methods: A panel of experts reviewed and graded the literature on platelet transfusions; recommendations were formulated.

Main findings: Threshold platelet counts (PC) for transfusions in the perioperative context have not been clearly defined and should be determined by the existence of hemorrhagic risk factors. In the case of commonly practiced invasive procedures, the recommendation is to transfuse in order to achieve PC $>50,000 \cdot \mu \mathrm{L}^{-1}$. In the absence of platelet dysfunction, regardless of the type of surgery, the standard hemorrhagic risk threshold for surgery is $50,000 \cdot \mu \mathrm{L}^{-1}$. It has not been proven that the risk threshold is different according to the type of surgery. For neurosurgery and ophthalmologic surgery involving the posterior segment of the eye, a PC of $100,000 \cdot \mu \mathrm{L}^{-1}$ is required. For axial regional anesthesia, a PC of $50,000 \cdot \mu \mathrm{L}^{-1}$ is sufficient for spinal anesthesia; a PC of $80,000 \cdot \mu \mathrm{L}^{-1}$ has been proposed for epidurals. During massive transfusion, prophylactic platelet infusion cannot be recommended beyond a loss of two blood volumes in less than 24 hr (Professional Consensus). As for the therapeutic transfusion of plasma and/or platelets, as much as possible, platelet deficit should be documented with test results (PC and fibrinogen) before transfusing. In the event of bleeding, platelet transfusion may precede plasma infusion. However, although this recommendation has been the subject of several professional consensus agreements, it is not based on any randomized studies.

Conclusion: Threshold PC for perioperative transfusions have not been clearly defined and most recommendations are the result of a professional consensus.
Objectif : Présenter les recommandations de l'Agence Française de Sécurité Sanitaire des Produits de Santé (AFSSaPS).

Méthode : Un panel d'experts a revu et évalué la documentation sur les transfusions de plaquettes ; des recommandations ont été formulées.

Constatations principales : Le décompte plaquettaire seuil (DP) pour les transfusions périopératoires n'est pas clairement défini et doit être déterminé par l'existence de facteurs de risque hémorragique. Dans le cas de gestes invasifs pratiqués fréquemment, on recommande de transfuser pour atteindre un DP $>50000 \cdot \mu \mathrm{L}^{-1}$. En l'absence de dysfonction plaquettaire, peu importe le type de chirurgie, le seuil du risque hémorragique normal de la chirurgie est de 50 $000 \cdot \mu L^{-1}$. On n'a pas prouvé que le seuil de risque dépend du type de chirurgie. En neurochirurgie, et ophtalmologique touchant le segment postérieur de l'œil, il faut un DP de $100000 \cdot \mu L^{-1}$. En anesthésie régionale axiale, un DP de $50000 \cdot \mu L^{-1}$ est suffisant pour la rachianesthésie ; un DP de $80000 \cdot \mu \mathrm{L}^{-1}$ a été proposé pour les péridurales. Pendant la transfusion massive, la perfusion prophylactique de plaquettes ne peut être recommandée au delà d'une perte de deux masses sanguines en moins de $24 \mathrm{~h}$ (Consensus professionnel). Comme pour la transfusion thérapeutique de plasma et/ou de plaquettes, autant que possible, le déficit de plaquettes doit être documenté avec les résultats de tests (DP et fibrinogène) avant de transfuser. En cas d'hémorragie, la transfusion de plaquettes peut précéder la transfusion de plasma. Cependant, même si cette recommandation a fait l'objet de certains accords du consensus professionnel, il n'est fondé sur aucune étude randomisée.

Conclusion : Le DP seuil pour les transfusions périopératoires n'a pas été clairement défini et la plupart des recommandations sont le résultat d'un consensus professionnel.

From the Département d'Anesthésie-Réanimation, Hôpital Avicenne, ${ }^{\star}$ Bobigny; Site transfusionnel Saint-Antoine, $†$ EFS Ile-de-France, Paris; Service d’Hématologie Biologique, CHU de Nancy, Nancy; Département d’Anesthésie-Réanimation Chirurgicale, Centre Hospitalier Universitaire Dupuytren, $§$ Limoges; Département d’Hématologie/Biologie, CHU Saint Eloi, Montpellier, France. Address correspondence to: Pr. Charles Marc Samama, Département d’Anesthésie-Réanimation, Hôpital Avicenne, 125, route de Stalingrad, 93009 Bobigny cedex, France. Phone: +33-1-48955591; Fax: +33-1-48955589; E-mail: cmsamama@invivo.edu Accepted for publication October 10, 2004. 
I N 2003, the Agence Française de Sécurité Sanitaire des Produits de Santé (AFSSaPS; French Safety Agency for Health Products) issued new recommendations on platelet transfusion to update the previous recommendations issued in 1997. A large working group was constituted, composed of several experts originating from different medical fields (anesthesiology, intensive care, transfusion medicine, hematology, immunology, pediatrics). The litterature was screened extensively, using several databases (Medline, Embase, etc) and after one year of intensive work and several meetings, an extensive review of the subject and the related recommendations became available. The texts were reviewed by a multidisciplinary reading committee whose comments were implemented in the final version. Recommendations were classified (grade) according to the evidence level of the studies supporting them (Table I). Finally, the texts were validated by the "Comité de validation des recommandations et Références médicales de l'AFSSaPS." Members of these three groups are listed in Appendix 1.

We have chosen to extract the perioperative section of these recommendations for the information of clinical anesthesiologists.

The original, integral version of the recommendations on platelet transfusions can be found on the website of the Agence Française de Sécurité Sanitaire des Produits de Santé: AFSSaPS (French Safety Agency for Health Products): http://www.agmed. sante.gouv.fr/htm/5/rbp/indrbp.htm

\section{Perioperative platelet transfusions: recommendations}

Threshold platelet counts (PC) for perioperative transfusions have not been clearly defined and should be determined by the existence of hemorrhagic risk factors:

The existence and severity of spontaneous bleeding syndrome or bleeding caused by a minor trauma.

- A history of bleeding or transfusions during previous minor surgery or invasive procedures.
- Associated hemostatic abnormality, particularly in the case of disseminated intravascular coagulation.

- Changes in platelet function induced by drugs or associated diseases: blood diseases (monoclonal gammopathy, myelodysplasia), kidney disease.

- Hypothermia, anemia, splenomegaly.

- Persistent shock, infection.

- Hypertension.

Regardless of the hemorrhagic risk assessment:

The procedure should always be performed by an experienced practitioner.

- The rapid availability of blood products should be ensured.

- Hemorrhagic risk factors should be corrected.

It is recommended, particularly for surgery, that non-specific methods of reduction of bleeding be used, i.e., (Professional Consensus):

First choose the method that provides the best surgical control of hemostasis.

- Maintain normothermia. ${ }^{1}$

- Limit hemodilution. ${ }^{2-4}$

- Ensure the early detection of a hemorrhagic syndrome requiring complementary surgical hemostasis. ${ }^{5}$

- Limit therapies interfering with hemostasis (anticoagulants, antiplatelet agents...) to strict indications. ${ }^{6}$

\section{Platelet transfusion before an invasive procedure or surgery in the event of thrombocytopenia Invasive procedure}

For common invasive procedures (transparietal liver biopsy, lumbar puncture, transbronchial endoscopic biopsy, gastrointestinal endoscopy with biopsy, placement of catheter, etc.) performed in thrombocytopenic patients, the recommendation is to transfuse platelets to achieve a PC $>50,000 \cdot \mu \mathrm{L}^{-1}($ Grade C $) .^{7,8}$ Post-transfusion PC should be monitored prior to the procedure. It is not necessary to systematically check the bleeding time. ${ }^{9,10}$

TABLE I Levels of evidence and grades of recommendations

\begin{tabular}{|c|c|c|}
\hline \multicolumn{2}{|c|}{ Level of evidence } & \multirow{2}{*}{$\begin{array}{l}\text { Grade of recommendation } \\
\text { Grade A: }\end{array}$} \\
\hline Level I: & $\begin{array}{l}\text { Large randomized trials with clear-cut results (and low risk of error) } \\
\text { Metaanalyses of randomised trials } \\
\text { Decision analysis based on well conducted studies }\end{array}$ & \\
\hline Level II: & $\begin{array}{l}\text { Small randomized trials with uncertain results } \\
\text { Well conducted non-randomized studies } \\
\text { Cohort studies }\end{array}$ & Grade B: \\
\hline $\begin{array}{l}\text { Level III: } \\
\text { Level IV: }\end{array}$ & $\begin{array}{l}\text { Case-control series } \\
\text { Comparative studies with major bias, } \\
\text { Retrospective studies, historical controls, case series, epidemiological studies }\end{array}$ & Grade C: \\
\hline
\end{tabular}




\section{Surgery}

In the absence of platelet dysfunction, regardless of the type of surgery, there is no hemorrhagic risk associated with thrombocytopenia alone for $\mathrm{PC}>$ $50,000 \cdot \mu \mathrm{L}^{-1}$. The risk is low for PC between 50,000 to $100,000 \cdot \mu \mathrm{L}^{-1}$. The standard threshold for hemorrhagic risk for surgery is therefore $50,000 \cdot \mathrm{\mu L}^{-1}$, including cardiac surgery with cardiopulmonary bypass (Professional Consensus). ${ }^{11-15}$

There is no proof that the risk threshold is different according to the type of surgery. Nonetheless, for neurosurgery and ophthalmologic surgery involving the posterior segment of the eye, a PC of $100,000 \cdot \mu \mathrm{L}^{-1}$ is required. ${ }^{16}$

For axial regional anesthesia:

a PC of $50,000 \cdot \mu \mathrm{L}^{-1}$ is deemed sufficient for spinal anesthesia.

a PC of $80,000 \cdot \mu \mathrm{L}^{-1}$ has been proposed for epidurals, but other hemorrhagic risk factors must be taken into account, particularly those cited previously, as well as the progressive nature of the thrombocytopenia. ${ }^{17-21}$

Aside from cases of massive transfusion, platelet transfusion is considered useful in cardiac surgery and major liver surgery (particularly liver transplantation and portocaval shunt).

In cardiac surgery, therapeutic platelet transfusion is justified if the $\mathrm{PC}<50,000 \cdot \mu \mathrm{L}^{-1}$ (Professional Consensus). Platelet transfusion is justified in the event of microvascular bleeding associated with $\mathrm{PC}<$ $100,000 \cdot \mu \mathrm{L}^{-1}$ (Grade B evidence).

In liver surgery, particularly transplantation, therapeutic platelet transfusion is justified if the PC is $50,000 \cdot \mu \mathrm{L}^{-1}$ (Grade C). Correction of other factors that foster bleeding such as hypovolemia, hypothermia and anemia is imperative and is an integral part of the platelet transfusion process.

In obstetrics, there is no indication for platelet transfusion in the case of gestational thrombocytopenia $^{22}$ in late pregnancy (also known as idiopathic thrombocytopenic purpura (Professional Consensus).

In the event of thrombocytopenia associated with hemolysis, elevated liver enzymes, and low platelets syndrome (HELLP) or preeclampsia, platelet transfusion is recommended immediately before a Cesarean section for a PC of less than $50,000 \cdot \mu \mathrm{L}^{-1}$ and immediately before vaginal delivery for a $\mathrm{PC}<30,000 \cdot \mu \mathrm{L}^{-1}$ (Professional Consensus).

In autoimmune thrombocytopenic purpura, transfused platelets are very rapidly destroyed, as are the patient's own platelets. Therefore, there is no indication for platelet transfusion, aside from life-threatening hemorrhagic emergencies (Professional
Consensus). In this case, they should be combined with intravenously administered immunoglobulin and high doses of corticosteroids.

\section{Platelet transfusion during an invasive procedure or surgery in the event of thrombopathy Hematologic thrombopathy}

Constitutional or acquired thrombopathy should be managed by specialists for an in-depth investigation. There is no proof that any specific test (particularly the bleeding time) can predict hemorrhagic risk in these patients.

\section{Drug-induced thrombopathy}

Drug-induced thrombopathies are the most frequent cause of acquired thrombopathy. ${ }^{23-30}$ The main drugs involved are platelet function inhibitors and nonsteroidal anti-inflammatory drugs, which have an effect on platelet function ${ }^{\mathrm{A}}$ (depending on the drug and the dosage).

\section{Drugs involved}

The hemorrhagic risks by type of surgery are presented in Appendix 2.

\section{Prophylaxis}

Prophylactic platelet transfusion before an invasive procedure, when platelet inhibitor therapy has not been discontinued in a timely manner, is not recommended (Professional Consensus).

\section{Role of transfusion}

There are no clinical studies validating the benefits of platelet transfusion in reducing the risk of bleeding (prophylactic administration) or in limiting bleeding when it occurs (therapeutic administration) in patients with drug induced thrombopathy. However, this is the only therapeutic option that can be envisaged in the event of severe hemorrhage (Professional Consensus).

\section{Platelet transfusion in the event of massive transfusion}

Several definitions for massive transfusion have been proposed: ${ }^{5,31-35}$

- Replacement of the loss of more than one blood volume in less than $24 \mathrm{hr}$.

- Replacement of the loss of more than $50 \%$ of blood volume in less than three hours.

- Blood loss of more than $150 \mathrm{~mL} \cdot \mathrm{min}^{-1}$.

A See experts' conference organized at the initiative of the Société française d'anesthésie et de réanimation (SFAR; the French Society of Anesthesiology and Intensive Care) on "Antiplatelet agents in the perioperative period", available at www.Sfar.org. 
TABLE II Proposals to help with therapeutic decision making

\begin{tabular}{|c|c|c|c|}
\hline & \multicolumn{3}{|c|}{ Presence of clinical bleeding } \\
\hline & & Yes & No \\
\hline \multirow[t]{3}{*}{$\begin{array}{l}\text { Presence of abnormal } \\
\text { laboratory tests* }\end{array}$} & Yes & $\begin{array}{l}\text { Transfusion of platelets and FFP based } \\
\text { on test results (starting with } \\
\text { (e.g., platelet concentrates) })^{* *}\end{array}$ & $\begin{array}{l}\text { Transfusion based } \\
\text { related to the procedure on risks } \\
\text { neurosurgery and } \mathrm{PC}<100,000 \cdot \mu \mathrm{L}-1)\end{array}$ \\
\hline & No & $\begin{array}{l}\text { Look for a cause } \\
\text { other than a hemostatic abnormality } \\
\text { Assess the extent of transfusions } \\
\text { and eventually transfuse platelets } \\
\text { and FFP if loss } \\
\text { exceeds one blood volume } \\
\text { (starting with platelets)** }\end{array}$ & No indication for transfusion \\
\hline & Unknown & $\begin{array}{l}\text { Monitor laboratory tests. } \\
\text { Transfusion based on the } \\
\text { probable type of hemostatic disorder }\end{array}$ & $\begin{array}{l}\text { No indication for transfusion } \\
\text { Repeat laboratory tests }\end{array}$ \\
\hline
\end{tabular}

*Platelets $<50,000 \cdot \mu \mathrm{L}^{-1}$, fibrinogen $<0.5$ to $0.8 \mathrm{~g} \cdot \mathrm{L}^{-1}$, prothrombin time and/or activated partial thromboplastin time $>1.5$ to 1.8 times control. ${ }^{*}$ Platelet transfusion could precede plasma infusion. Although this recommendation has been made by several professional consensus statements, it is not based on any randomized trials. FFP $=$ fresh frozen plasma.

Treatment priorities are:

- Restore blood volume to maintain tissue perfusion and oxygenation.

- Control hemostasis by treating the cause of bleeding and by correcting the coagulopathy with an appropriate choice of blood products.

\section{Prophylactic platelet transfusions based on volume replaced}

Prophylactic infusion of platelets is not recommended beyond the replacement of two blood volumes in less than $24 \mathrm{hr}$ (Professional Consensus).

It is important to consider the individual clinical situation and reasons for bleeding. It is likely but not certain that the preventive administration of platelets is not useful if the patient is not bleeding.

Fresh frozen plasma (FFP) should be transfused at the same time as platelets.

\section{Therapeutic platelet transfusion}

Abnormal bleeding is bleeding that is unexpected and does not respond either to compression or to electrocoagulation. Although clinical assessment remains an important element in the decision making process, alone is not a sufficient indication for transfusion.

\section{Transfusion of FFP or platelets}

As much as possible, it is desirable to document platelet deficits with test results (PC and fibrinogen) before transfusing.

It is also desirable to closely monitor PC and fibrinogen and to begin with platelet concentrates
(Professional Consensus). A number of authors suggest using point of care coagulation monitors for surgical bleeding. ${ }^{36}$

Other elements involved in increased hemostatic problems during massive transfusion

Hypothermia interferes with hemostasis. It is imperative that all available techniques be used to warm the patient as well as the infusion and transfusion products. ${ }^{1,37,38}$ A drop in hematocrit increases the risk of bleeding, particularly in the presence of thrombocytopenia. Infusion of packed red blood cells should not be delayed. ${ }^{2-4}$ Hemostatic problems observed during massive transfusion are increased by shock. Optimization of the patient's hemodynamic status is an essential objective. ${ }^{39}$ If a multiple trauma victim with multiple transfusions has a head injury, perioperative hemostasis should be controlled even further (earlier infusion of plasma, platelets).

Table II summarizes the available information and proposes a therapeutic transfusion protocol based on the presence/absence of clinical bleeding and the results of laboratory tests.

\section{References}

1 Reed RL II, Johnston TD, Hudson JD, Fischer RP. The disparity between hypothermic coagulopathy and clotting studies. J Trauma 1992; 33: 465-70.

2 Escolar G, Garrido M, Mazzara R, Castillo R, Ordinas $A$. Experimental basis for the use of red cell transfusion in the management of anemic-thrombocytopenic patients. Transfusion 1988; 28: 406-11. 
3 Santos MT, Valles J, Marcus AJ, et al. Enhancement of platelet reactivity and modulation of eicosanoid production by intact erythrocytes. A new approach to platelet activation and recruitment. J Clin Invest 1991; 87: 571-80.

4 Ouaknine-Orlando B, Samama CM, Riou B, et al. Role of the hematocrit in a rabbit model of arterial thrombosis and bleeding. Anesthesiology 1999; 90: 1454-61.

5 Stainsby D, MacLennan S, Hamilton PJ. Management of massive blood loss: a template guide. Br J Anaesth 2000; 85: 487-91.

6 Samama CM, Bastien O, Forestier F, et al. Antiplatelet agents in the perioperative period: expert recommendations of the French Society of Anesthesiology and Intensive Care (SFAR) 2001 - summary statement. Can J Anesth 2002; 49(Suppl): S26-35.

7 Cadranel JF, Rufat P, Degos F. Practices of transcutaneous liver biopsies in France. Results of a retrospective nationwide study (French). Gastroenterol Clin Biol $2001 ; 25$ : 77-80.

8 Weiss SM, Hert RC, Gianola FJ, Clark JG, Crawford $S W$. Complications of fiberoptic bronchoscopy in thrombocytopenic patients. Chest 1993; 104: 1025-8.

9 Rodgers RP, Levin J. A critical reappraisal of bleeding time. Semin Thromb Hemost 1990; 16: 1-10.

10 O'Kelly SW, Lawes EG, Luntley JB. Bleeding time: is it a useful clinical tool? Br J Anaesth 1992; 68: 313-5.

11 College of American Pathologists. Practice parameter for the use of fresh-frozen plasma, cryoprecipitate, and platelets. Fresh-Frozen Plasma, Cryoprecipitate, and Platelets Administration Practice Guidelines Development Task Force of the College of American Pathologists. JAMA 1994; 271: 777-81.

12 Rebulla $P$. Trigger for platelet transfusion. Vox Sang 2000; 78(Suppl )2: 179-82.

13 Consensus conference. Platelet transfusion therapy. JAMA 1987; 257: 1777-80.

14 Murphy MF, Brozovic B, Murphy W, Ouwehand W, Waters $A H$. Guidelines for platelet transfusions. British Committee for Standards in Haematology, Working Party of the Blood Transfusion Task Force. Transfus Med 1992; 2: 311-8.

15 Contreras $M$. Final statement from the consensus conference on platelet transfusion. Transfusion 1998; 38: 796-7.

16 Hay A, Olsen KR, Nicholson DH. Bleeding complications in thrombocytopenic patients undergoing ophthalmic surgery. Am J Ophtalmol 1990; 109: 482-3.

17 Rolbin SH, Abbott D, Mutsclow E, Papsin F, Lie LM, Freedman J. Epidural anesthesia in pregnant patients with low platelet counts. Obstet Gynecol 1988; 71: 918-20.
18 Edelson RN, Chernik NL, Posner JB. Spinal subdural hematomas complicating lumbar puncture. Arch Neurol 1974; 31: 134-7.

19 Beilin Y, Zahn J, Comerford M. Safe epidural analgesia in thirty parturients with platelet counts between 69,000 and 98,000 mm(-3). Anesth Analg 1997; 85: 385-8.

20 Hew-Wing P, Rolbin SH, Hew E, Amato D. Epidural anaesthesia and thrombocytopenia. Anaesthesia 1989; 44: 775-7.

21 Vandermeulen EP, Van Aken H, Vermylen J. Anticoagulants and spinal-epidural anaesthesia. Anesth Analg 1994; 79: 1165-77.

22 Burrows RF, Kelton JG. Thrombocytopenia at delivery: a prospective survey of 6715 deliveries. Am J Obstet Gynecol 1990; 162: 731-4.

23 Lecompte T. Inhibiteurs du fonctionnement plaquettaire et chirurgie. In: Samama CM, de Moerloose P, Hardy JF, Sié P, Steib A (Eds). Hémorragies et Thromboses Périopératoires en Anesthésie-Réanimation: Approches Pratiques - Groupe d'Intérêt en Hémostase Périopératoire (GIHP). Paris: Masson; 2000: 77-87.

24 Schafer $A I$. Effects of nonsteroidal anti-inflammatory therapy on platelets. Am J Med 1999; 106: 25S-36S

25 van Hecken A, Schwartz JI, Depré M, et al. Comparative inhibitory activity of rofecoxib, meloxicam, diclofenac, ibuprofen, and naproxen on cox-2 versus cox-1 in healthy volunteers. J Clin Pharmacol 2000; 40: 1109-20.

26 Patrono C. Antiplatelet strategies. Eur Heart J 2002; 4: A42-7.

27 FitzGerald GA, Patrono $C$. The coxibs, selective inhibitors of cyclooxygenase-2. N Engl J Med 2001; 345: 433-42.

28 Collaborative overview of randomised trials of antiplatelet therapy - II: Maintenance of vascular graft or arterial patency by antiplatelet therapy. Antiplatelet Trialists' Collaboration. BMJ 1994; 308: 159-68.

29 Topol EJ, Byzova TV, Plow EF. Platelet GPIIb-IIIa blockers. Lancet 1999; 353: 227-31.

30 Gammie JS, Zenati M, Kormos RL, et al. Abciximab and excessive bleeding in patients undergoing emergency cardiac operations. Ann Thorac Surg 1998; 65: 465-9.

31 Hiippala $S$. Replacement of massive blood loss. Vox Sang 1998; 74 (Suppl 2): 399-407.

32 Hiippala ST, Myllylä GJ, Vabtera EM. Hemostatic factors and replacement of major blood loss with plasmapoor red cell concentrates. Anesth Analg 1995; 81: 360-5.

33 Harvey MP, Greenfield TP, Sugrue ME, Rosenfeld D. Massive blood transfusion in a tertiary referral hospital. Clinical outcomes and haemostatic complications. Med 
J Aust 1995; 163: 356-9.

34 Hakala P, Hiippala S, Syrjala M, Randell T. Massive blood transfusion exceeding 50 units of plasma poor red cells or whole blood: the survival rate and the occurrence of leukopenia and acidosis. Injury 1999; 30: 619-22.

35 Reed RL, Ciavarella D, Heimbach DM, et al. Prophylactic platelet administration during massive transfusion. Ann Surg 1986; 203: 40-8.

36 Despotis GJ, Santoro SA, Spitznagel E, et al. Prospective evaluation and clinical utility of on-site monitoring of coagulation in patients undergoing cardiac operation. J Thorac Cardiovasc Surg 1994; 107: 271-9.

37 Michelson AD, MacGregor H, Barnard MR, Kestin AS, Rohrer MJ, Valeri CR. Reversible inhibition of human platelet activation by hypothermia in vivo and in vitro. Thromb Haemost 1994; 71: 633-40.

38 Rohrer MJ, Natale AM. Effects of hypothermia on the coagulation cascade. Crit Care Med 1992; 20: 1402-5.

39 Hewson JR, Neame PB, Kumar N, et al. Coagulopathy related to dilution and hypotension during massive transfusion. Crit Care Med 1985; 13: 387-91. 


\section{APPENDIX 1}

Working group

Pr MICHALLET Mauricette, President, Lyon

Dr NOUYRIGAT Emmanuel, Afssaps

Dr DUMARCET Nathalie, Afssaps

Dr BOURHIS Hean-Henri, Villejuif

Pr CAZENAVE Jean-Pierre, Strasbourg

Pr CLARIS Olivier, Lyon

Dr DAVID Bernard, Afssaps

Dr DECONINCK Eric, Besançon

Dr DENIS Catherine, Afssaps

Dr DJOUDI Rachid, Paris

Pr DUFOUR Patrick, Strasbourg

Dr FOLLEA Gilles, Nantes

Dr KAPLAN-GOUET Cécile, Paris

Pr LECOMPTE Thomas, Vandoeuvre les Nancy

Dr LEFRERE François, Paris

Pr MARIE Jean-Pierre, Paris

Dr MERCADIER Anne, Paris

Pr NATHAN-DENIZOT Nathalie, Limoges

Dr OUNNOUGHENE Afssaps

Pr SAMAMA Marc, Bobigny

Dr SANDID Afssaps

Pr SCHVED Jean-François, Montpellier

Dr SUTTON Laurent, Paris

Dr TRAINEAU Richard, Paris

Dr VEY Norbert, Marseille

Review group

Dr CHABERNAUD Jean-Louis, Clamart

Dr CLUET-DENNETIERE Sophie, Compiègne

Dr DENNINGER Marie-Hélène, Clichy

Dr FAVIER Rémi, Paris

Dr FORESTIER François, Bordeaux

Pr HARDY Jean-François, Montréal

Dr HERNANDORENA José-Xavier, Bayonne

Pr HERVE Patrick, Besançon

Pr IFRAH Norbert, Angers

Pr JANVIER Gérard, Pessac

Pr JOUSSEMET Marcel, Clamart

Dr LAPIERRE Valérie, Besançon

Dr LASNE Dominique, Paris

Dr LEPEU Gérard, Avignon

Pr LONGROIS Dan, Nancy

Pr MILPIED Noël, Nantes

Pr MULLER Jean-Yves, Nantes

Dr PIGNON Bernard, Reims

Pr RIOU Bruno, Paris

Dr SENSEBE Luc, Tours

Pr SIE Pierre, Toulouse

Pr SIMEONI Umberto, Marseille

Pr STEIB Annick, Strasbourg

Pr VAN DER LINDEN Philippe, Jumet

Pr TCHERNIA Gilbert, Le Kremlin Bicêtre

\section{Validation Commmittee}

Pr BOUVENOT Gilles, President, Marseille

Pr BERGMANN Jean-François, Vice-President, Paris

Dr CARON Jacques, Lille

Pr CAULIN Charles, Paris

Pr CHOUTET Patrick, Tours

Pr DUPUIS Bernard, Lille

Pr JOLLIET Pascale, Nantes

Dr AMBROSI Pierre, Marseille

Dr ATLAN Pierre, Paris

Pr BANNWARTH Bernard, Bordeaux

Dr CAMELLI Bruno, Paris

Dr CUCHERAT Michel, Lyon

Dr DEMOLIS Pierre, le Kremlin Bicêtre

Dr DENIS Catherine, Afssaps

Pr DIQUET Bertrand, Angers

Dr DUMARCET Nathalie, Afssaps

Dr GUEYFFIER François, Lyon

Dr HANSLIK Thomas, Boulogne Billancourt

Dr LE ROUX Gérard, Epinay sous Sénart

Dr LIEVRE Michel, , Lyon

Dr MEYER François, Afssaps

Pr PETIT Michel, Sotteville-lès-Rouen

Dr REVEILLAUD Olivier, Bièvres

Pr RICHÉ Christian, Brest

Dr ROSTOKER Guy, Afssaps

Dr TREMOLIERES François, Mantes-la-Jolie

Pr TROUVIN Jean-Hugues, Afssaps

Dr WONG Olivier, Paris 


\section{APPENDIX 2}

Drugs most often involved in abnormal platelet function in surgical patients

\begin{tabular}{|c|c|c|c|c|}
\hline Type of surgery & Drug therapy & Situation & Hemorrhagic risk & $\begin{array}{l}\text { Level of } \\
\text { evidence }\end{array}$ \\
\hline \multirow[t]{5}{*}{ Hip surgery } & $\begin{array}{l}\text { Aspirin } 100 \mathrm{mg} \text { with } \\
\text { prophylactic heparin }\end{array}$ & Preoperative & $\begin{array}{l}\text { Increased risk } \\
\text { and exposure to transfusion }\end{array}$ & 1 \\
\hline & $\begin{array}{l}\text { Aspirin and other NSAIDs } \\
\text { (without heparin) }\end{array}$ & Preoperative & $\begin{array}{l}\text { Possible increase in risk } \\
\text { and exposure to transfusion }\end{array}$ & 3 \\
\hline & Aspirin (alone) & Postoperative & $\begin{array}{l}\text { No increased risk } \\
\text { or exposure to transfusion }\end{array}$ & 1 \\
\hline & $\begin{array}{l}\text { NSAIDs with prophylactic } \\
\text { heparin }\end{array}$ & Postoperative & $\begin{array}{l}\text { No increased risk } \\
\text { or exposure to transfusion }\end{array}$ & 1 \\
\hline & NSAIDs & Postoperative & $\begin{array}{l}\text { No increased risk } \\
\text { or exposure to transfusion }\end{array}$ & 2 \\
\hline \multirow[t]{2}{*}{ Knee surgery } & Aspirin (alone) & Postoperative & $\begin{array}{l}\text { No increased risk } \\
\text { or exposure to transfusion }\end{array}$ & 1 \\
\hline & NSAIDs & Postoperative & $\begin{array}{l}\text { No increased risk } \\
\text { or exposure to transfusion }\end{array}$ & 2 \\
\hline \multirow[t]{4}{*}{ Cardiac surgery } & Aspirin and other NSAIDs & Preoperative & $\begin{array}{l}\text { Modest increase in } \\
\text { risk with few changes in } \\
\text { transfusion requirements }\end{array}$ & $2-4$ \\
\hline & Abciximab (plus aspirin) & Preoperative & $\begin{array}{l}\text { Possible increase in risk } \\
\text { and exposure to transfusion }\end{array}$ & 3 \\
\hline & $\begin{array}{l}\text { Eptifibatide, tirofiban } \\
\text { (plus aspirin) }\end{array}$ & Preoperative & $\begin{array}{l}\text { Possible increase in risk } \\
\text { and exposure to transfusion, } \\
\text { but less than with abciximab }\end{array}$ & 3 \\
\hline & Thienopyridine & Preoperative & $\begin{array}{l}\text { Possible increase in risk } \\
\text { or exposure to transfusion }\end{array}$ & 4 \\
\hline Carotid artery surgery & Aspirin & Preoperative & $\begin{array}{l}\text { No increased risk of } \\
\text { cervical hematoma or } \\
\text { intracranial bleeding* }\end{array}$ & 3 \\
\hline Tonsillectomy & NSAIDs including aspirin & Pre- or postoperative & $\begin{array}{l}\text { Possible increased risk } \\
\text { and revision procedures for hemostasis }\end{array}$ & $1-3$ \\
\hline \multirow[t]{2}{*}{$\begin{array}{l}\text { Anterior chamber, } \\
\text { avascular structures } \\
\text { (lens, cornea) } \\
\text { Strabismus surgery }\end{array}$} & Aspirin & Preoperative & Small increase in risk & 2 \\
\hline & NSAIDs & Postoperative & No increased risk & 2 \\
\hline \multirow{2}{*}{$\begin{array}{l}\text { Intracranial surgery } \\
\text { Prostate via } \\
\text { abdominal approach }\end{array}$} & All platelet function inhibitors & Preoperative & Increased risk & $3-4$ \\
\hline & NSAIDs & Postoperative & $\begin{array}{l}\text { Low increase in risk with no } \\
\text { increase in transfusion requirements }\end{array}$ & 2 \\
\hline \multicolumn{5}{|l|}{$\begin{array}{l}\text { Transurethral prostatic } \\
\text { resection }\end{array}$} \\
\hline & Aspirin & Preoperative & $\begin{array}{l}\text { Possible increase in risk and } \\
\text { transfusion requirements }\end{array}$ & 3 \\
\hline & Ticlopidine & Pre- or postoperative & $\begin{array}{l}\text { Increased risk and } \\
\text { transfusion requirements }\end{array}$ & 2 \\
\hline & Aspirin and other NSAIDs & Preoperative & Contradictory findings & $2-3$ \\
\hline $\begin{array}{l}\text { Gastrointestinal and } \\
\text { general surgery }\end{array}$ & $\begin{array}{l}\text { NSAIDs if patient is less than } \\
75 \text { yr old }\end{array}$ & $\begin{array}{l}\text { Postoperative by less } \\
\text { than } 5 \text { days }\end{array}$ & $\begin{array}{l}\text { No increased risk or revision } \\
\text { procedures for hemostasis }\end{array}$ & 3 \\
\hline \multicolumn{5}{|l|}{ General } \\
\hline \multirow{3}{*}{$\begin{array}{l}\text { Vaginal delivery } \\
\text { Cesarean }\end{array}$} & Thienopyridines & Preoperative & High increase in risk & $3-4$ \\
\hline & Aspirin & Before & $\begin{array}{l}\text { No increase in the incidence } \\
\text { or severity of hemorrhage } \\
\text { during delivery. }\end{array}$ & 2 \\
\hline & NSAIDs & $?$ & No increased risk & 2 \\
\hline
\end{tabular}

* For carotid surgery, the only randomized placebo-controlled trial studied the pre- and postoperative administration (one single dose) of low-dose aspirin $(75 \mathrm{mg})$, and pre-operative anticoagulation with heparin was neutralized by postoperative administration of protamine. 